\title{
Competing in the Era of Industrial Revolution 4.0 and Society 5.0
}

\section{Lena Ellitan}

Management Study Program, Widya Mandala Catholic University Surabaya, Indonesia Author correspondence: lena@mail.wima.ac.id; ellistya@yahoo.com

\begin{abstract}
The industrial revolution 4.0 presents challenges that must be faced by the business world, namely the lack of adequate HR (Human Resource) skills, the problem of security of communication technology, the reliability of the stability of production machines, the inability to change by stakeholders, and the number of job losses due to automation. Society 5.0 offers a human-centered society that makes a balance between economic progress and the resolution of social problems through a system that is highly connected through cyberspace and the real world. If society 4.0 allows anyone to access also share information on the internet. Society 5.0 is an era where all technology is part of humanity itself. To take advantage of opportunities and answer the challenges of the industrial revolution 4.0, Indonesian people, in particular, are required to have data, technology, and human literacy capabilities. Data literacy is needed by HR to improve skills in processing and analyzing big data for the benefit of improving public and business services. Technology literacy shows the ability to utilize digital technology to process data and information, while human literacy must be mastered because it shows the element of soft skills or the development of individual character to be able to collaborate, be adaptive, and innovative. Indonesia is demanded to be able to follow industry 4.0 workflows juxtaposed with society 5.0. The need for human resources (HR) in several business fields is still very massive if all of them are carried out by robotics. Indonesia is a developing country with a fairly dense population that is certainly able to align between the needs of industry 4.0 and society 5.0. Leadership in organizations must stay alive so that every innovative competitive strategy can run with the existing vision. To go to the era of society 5.0 , the government is obliged to continuously control it.
\end{abstract}

Keywords: HR skills and literacy; Industrial revolution 4.0; Opportunity and threat; Society 5.0.

Abstrak. Revolusi industri 4.0 menghadirkan tantangan yang harus dihadapi oleh dunia bisnis, yaitu kurangnya ketrampilan SDM (sumber daya manusia) yang memadai, masalah keamanan teknologi komunikasi, keandalan stabilitas mesin produksi, ketidakmampuan untuk berubah oleh pemangku kepentingan, dan sejumlah pekerjaan yang hilang karena otomatisasi. Masyarakat 5.0 menawarkan masyarakat yang berpusat pada manusia yang 
membuat keseimbangan antara kemajuan ekonomi dan penyelesaian masalah sosial melalui sistem yang terhubung erat antara dunia maya dan dunia nyata. Jika masyarakat 4.0 memungkinkan siapa pun untuk mengakses, juga berbagi informasi melalui internet, maka masyarakat 5.0 adalah era ketika semua teknologi adalah bagian dari kemanusiaan itu sendiri. Untuk memanfaatkan peluang dan menjawab tantangan revolusi industri 4.0, masyarakat Indonesia khususnya, diharuskan memiliki data, teknologi, dan kemampuan literasi manusianya. Literasi data diperlukan oleh SDM untuk meningkatkan ketrampilan dalam memproses dan menganalisis data besar bagi kepentingan untuk meningkatkan layanan publik dan bisnis. Literasi teknologi menunjukkan kemampuan untuk memanfaatkan teknologi digital guna memproses data dan informasi, sedangkan literasi manusia harus dikuasai karena menunjukkan unsur soft skill atau pengembangan karakter individu untuk dapat berkolaborasi, adaptif, dan inovatif. Indonesia dituntut mampu mengikuti alur kerja industri 4.0 yang disandingkan dengan masyarakat 5.0. Kebutuhan sumber daya manusia di beberapa bidang bisnis masih sangat besar, apabila semuanya dilakukan oleh robot. Indonesia adalah negara berkembang dengan populasi yang cukup padat dan mampu menyelaraskan antara kebutuhan industri 4.0 dan masyarakat 5.0. Kepemimpinan dalam organisasi harus tetap hidup, sehingga setiap strategi kompetitif yang inovatif dapat berjalan dengan visi yang ada. Untuk menyongsong era masyarakat 5.0, pemerintah berkewajiban untuk selalu mengendalikannya.

Kata kunci: $\quad$ Ketrampilan dan kemampuan SDM; Masyarakat 5.0; Peluang dan ancaman; Revolusi industri 4.0.

\section{Article Info:}

Received: March 7, $2020 \quad$ Accepted: May 26, 2020

Available online: July 15, 2020

DOI: http://dx.doi.org/10.30588/jmp.v10i1.657

\section{BACKGROUND}

The industrial revolution is a major change in the field of technology that causes changes in the way of human life and work processes fundamentally, where the advancement of information technology can integrate in the world of life with digital that can give the impact of scientific disciplines. The occurrence of the industrial revolution 4.0 makes a new face in the phase of technological progress. The industrial revolution began in 1750 and was commonly called the industrial revolution 1.0 when a steam engine was invented. The 2.0 industrial revolution began when there was a change in the use of steam engines to machines that use electricity. The 3.0 industrial revolution began when the production process was using machines that were able to move and be controlled, began using simple robots, to the use of computers.

At present, the industrial revolution has reached a higher stage called the industrial revolution 4.0. In this era the system is directed to digital forms assisted with networks. In Indonesia the industrial revolution 4.0 has penetrated in various fields of life such as government, transportation, education, health and economy (Natalia \& Ellitan, 2019). This has resulted in changes and impacts felt by the community, both as actors (the business 
world) and users (consumers). The 4.0 industrial revolution brought manufacturing technology into the trend of automation and data exchange. This includes cyberphysical systems, internet of things (IoT) and cognitive computing. With the birth of current digital technology in the 4.0 industrial revolution impacted human life throughout the world (Muljani \& Ellitan, 2019).

Tjandrawinata (2016), argues that the rapid development of information technology is happening now that automation is happening in all fields, technologies and new approaches that are more fundamentally utilizing digitalization. The industrial revolution 4.0 presents challenges that must be faced by the business world, namely the lack of adequate HR skills, the problem of security of communication technology, the reliability of the stability of production machines, the inability to change by stakeholders, and the number of job losses due to automation. Society 5.0 offers a human-centered society that makes a balance between economic progress and the resolution of social problems through a system that is highly connected through cyberspace and the real world. The concepts of the industrial revolution 4.0 and society 5.0 do not have much difference. The industrial revolution 4.0 uses artificial intelligence while society 5.0 focuses on the human component. The concept of society 5.0 has become a new innovation from society 1.0 to society 4.0 in the history of human civilization (Mayasari, 2019).

\section{THEORETICAL REVIEW}

\section{Competitive Strategy and Strategic Orientation}

Strategies are made at the business or company level, directing every activity and behavior within the company to build excellence and improve business performance. Strategy is a tool for creating solutions to problems faced by the company and also capturing various opportunities that exist in the company's external environment (Obeidat, 2016). According to Huff, Floyd, Sherman, and Terjesen (2009), strategy is one of the tools trusted by managers in the company that influences the achievement of company performance. The strategy applied between corporate strategy and functional strategy, that is strategy at the business level (strategic orientation) related to how companies can compete effectively in each product and market chosen. Porter (1981) classifies strategies that are generic strategies at the level namely Cost Efficiency and Product Differentiation, which can also be seen as alternatives to the conceptualization of strategic orientation.

To build sustainable competitive advantage, it is also very much determined by how the company establishes a strategic orientation. Strategic orientation is the means used by companies to manage and carry out activities in business and efforts to maintain and improve business performance (Hakala, 2010). According to (Puspita, Christiananta, \& Ellitan, 2020), strategic orientation are principles that direct and influence company activities and build behaviors that are directed to ensure business success and performance (Puspita et al., 2020). Hakala (2010) states that strategic orientation consists of four different perspectives to measure the elements of strategy that affect business performance, namely the market orientation, entrepreneurial, technology and learning orientation. These four things are the direction of how a company runs its activities. The dynamics of a dynamic business environment with changes and increasingly fierce competition, it is not 
possible for organizations to take a traditional, hierarchical and top-down approach to management.

Several Strategic Orientation concepts were developed with different perspectives and approaches and their relationship to company performance. How is the strategy as an important part in strategic management to see the company's internal and external environment that is able to build competitive advantage that affects company performance. According to Huff et al. (2009), strategy is to define and communicate what is created in the organization, by whom, how, to whom and why it is valuable. While performance is a factor that is above management control, organizational strategy is the main tool trusted by managers that can influence the performance of the company they manage.

Hakala (2010) sees that Strategic Orientation is a combination of a company's value position in its market, its resources and behavioral patterns related to how an organization converts resources into products and services that are of value to its target market. Determining the right strategic orientation will affect the company's competitive advantage, especially in today's competition. Strategic orientation is a complementary resource that produces a synergy effect on performance (Tutar, Nart, \& Bingol, 2015). Ho's study (2014) looked at four dimensions of orientation namely market orientation, entrepreneurial, relationship and technology orientation. In contrast to the Hakala study (2010) which looks at four dimensions namely market, entrepreneurial, technology and learning orientation. Ho (2014) sees learning orientation as having a similarity to market orientation. The competitive strategy and strategic orientation in the theories developed have relevance to how companies and industry 4.0 can have competitiveness in society 5.0.

\section{Competitive Strategy of Industry 4.0}

The term Indonesia 4.0 must be familiar to us. The beginning of this term is the occurrence of industrial revolutions throughout the world, which is a fourth industrial revolution. It can be said as a revolution, because the changes that occur have a profound effect on the world's ecosystems and ways of life. The 4.0 industrial revolution is even believed to be able to significantly improve the economy and quality of life. Competitive strategies will determine company performance (Anis, Christiananta, \& Ellitan, 2018). The competitive strategy is seen externally while the positioning strategy is seen internally. Differentiation is a market difference so that it does not have in common with other markets/markets in a company or institution, which gives reasons for consumers to buy products or use company services. This strategy can be seen in the aviation industry, Garuda vs. Citilink. Linkages with industry 4.0 companies must be able to set competitive strategies and continue to innovate that are sometimes unknown when things change or cannot be predicted.

To be able to compete sustainably requires sensitive human resources (HR) and leaders who are keen to see opportunities and dare to make reforms if they want to remain in the vortex of today's business with its competitors. The industrial revolution is a rapid change in the economy and production in the form of increased efficiency which causes influence to other fields of life. Until now there have been 4 industrial revolutions starting from the 1.0 industrial revolution, and now what is happening is the 4.0 revolution. The Industrial Revolution 4.0 is the fourth industrial revolution. In the fourth industrial revolution the term machine learning was introduced, which is a machine that has the ability to 
learn that can realize that it made a mistake so that it makes correct corrections to improve subsequent results. However, machine learning is still limited to doing certain things. In Indonesia, the industrial revolution greatly affected every area of life (Hamdanunsera, 2018).

Currently what can be seen daily in the business world is online transportation (GoJek and Grab), online shopping, and the enactment of electronic money. However, besides having a positive impact, the negative impact of the 4.0 industrial revolution is also unavoidable (Natalia \& Ellitan, 2019). Not only Indonesia, in developed countries such as Japan, Germany, and the United States alone are still debating the consequences of this fourth industrial revolution, because this revolution is still ongoing or even arguably just beginning. Some multinational and national companies such as; Apple, Inc. and Go-Jek, from the standpoint of competitive strategy have their own market share compared to their rivals. Apple's market composition rises little by little but is more certain and focused. Work culture and leadership and innovation continue to make Apple able to survive and compete with other products from Europe and Asia. The Go-Jek company as a means of transportation is able to compete competitively with its Malaysian rival Grab, which has survived to this day. Utilizing digital applications and the reasons for their establishment in order to ease the use of transportation reduce traffic jams.

Its existence is the same as Traveloka which absorbs public attention. Traveloka's large market value invites foreign capital to Indonesia. Industry 4.0 is characterized by creativity, leadership (entrepreneurship) and entrepreneurship (entrepreneurship) which broke the "mindset" of how the previous industrial revolution worked. By having efficiency in communication and transportation and directing people to solve problems with a "one stop shopping" or "one stop solution" system, an atmosphere of the business world is needed that is free from bureaucratic constraints and obstacles and it is not just a matter of working but also an employee and labor mentality. it works. In turn, the output of this revolution is pretty much to bring benefits and prosperity such as cheap goods prices and guaranteed health. The need for supporting tools in the field of education is becoming more advanced and encouraging the nation's children to learn to excel or at least have the same intelligence capabilities as other nations. On the other hand the negative impact of industry 4.0 will gradually change the management system in the company where some work positions no longer need human labor. In the future, more companies using advanced technology machines/tools will be able to replace human functions by reason of time and labor efficiency. Such conditions require technological readiness for companies in industry 4.0. both large companies and SMEs (Ellitan \& Muljani, 2019).

Some of the challenges that must be faced in the industrial revolution 4.0 are the first is security, the second is capital, then the third is employment, and the fourth is privacy. However, there are some benefits that can be generated by the 4.0 industrial revolution is to encourage research, adjustment and optimization. Then, there are several principles in the industrial revolution that allow each company to identify and implement various scenarios of the industrial revolution 4.0 as follows: First is Interoperability, which is like the ability of machines, devices, sensors, and humans to connect and communicate with one another. through media where the internet. Second is information transparency, can provide information system capabilities in licensing the physical world by enriching digital factory 
models and with data sensors, and the third is the existence of technical assistance, namely the ability of assistance systems in helping humans to collect data and make visualizations to be able to make decisions good and wise like the one done by Microsoft and Astra.

\section{DISCUSSIONS}

\section{Industry 4.0 and Society 5.0}

The presence of the internet of things (IoT) in industry 4.0 gave birth to new ideas from Japanese civilization namely; society 5.0 presented at the 2019 World Economic Forum in Davos, Switzerland. This idea arose from the response of the Industrial Revolution 4.0 as a significant technological development but the role of the community was very much a consideration for the occurrence of this industrial revolution 4.0. Quoting from the World Economic Forum (WEF), the statement of the Japanese prime minister, Shinzo Abe explained "in society 5.0 it is no longer capital but data that connects and moves everything, helping to fill the gap between the rich and the disadvantaged. Medical and education services, from elementary to tertiary level, will reach small villages." If society 4.0 allows people to access and share information on the internet, society 5.0 is an era where all technology is part of humanity itself (Yunda, 2019).

The internet is not only as information but to live life. So that technological developments can minimize the gap in humans and economic problems in the future. An example of a company is Astra. Known in 2014, Astra conducted a study starting from the transformation of the internet from business enablers to business driven. 2016 is Astra's fundamental step to balance the presence of the 4.0 industrial revolution in the company's work order. In 2017, Astra accelerated its digital initiatives, especially responding to VUCA, namely, Volatile, Uncertain, Complex, and Ambigue is a picture of the situation in the business world today. Until 2019, Astra has set digitalization as a milestone in the direction of business in the future. Human resources then are not forgotten. Astra is still able to sort out digitization with the needs of Leadership Competencies that have been adjusted to its key of behavior according to the characteristics of the future of work. Competencies are vision and business sense, customer focus, planning and driving actions, analysis and judgment, teamwork, leading and motivating interpersonal skills, and drive and courage. Astra leadership competence is the core of the recruitment process, people mapping to development. Thus, Astra expects that in the future it can recruit HR in the context of the future of work (Usman, 2019).

If society 4.0 allows us to access also share information on the internet. Society 5.0 is an era where all technology is part of humanity itself. The internet is not only as information but to live life (Mayasari, 2019), so that technological developments can minimize the gap in humans and economic problems in the future. Indonesia is a developing country that can even be said to be only a small proportion of people who are familiar with the Industrial Revolution 4.0 or society 5.0. Only among academics who are literate about the progress of their times, business people who do have a business continuity interest, are also concerned public policy makers. Educational institutions which are categorized as superior in Indonesia have not yet implemented the industry 4.0 and society 5.0 system. From the start of the education system, how to interact educators and educated 
people, is only limited to the application of the curriculum. Fertilizing the paradigm of modern thinking is not yet all flat.

Indonesia has been implementing 4.0 for almost nine years, but it is still considered relatively slow. The government is trying to promote continuous improvement in the quality of human resources through adequate education and infrastructure support. The same thing happened in the manufacturing industry. Indonesia still tends to import goods from abroad, especially from China. Even though this country has been moving very rapidly in terms of the economy and its distribution and manufacturing. Indonesia is expected to be able to start reducing imports of goods, trying to make and be creative of goods products that can penetrate the global market. The industrial era 4.0 and society 5.0 will soon go hand in hand. In developed countries such actions have taken place. Japan is a concrete example of the initiator of the birth of society 5.0. Japan has ambitions to digitize all aspects of life given the worsening labor crisis and the rapid aging of the population in the country. Japan's readiness towards the era of society 5.0 has actually begun to be introduced in June 2017. At that time, the Japanese Prime Minister's Office released strategic details, including the use of new technology to solve social and economic problems.

Society 5.0 is not just about technology, but also policy and regulation. The Japanese government encourages local businesses to share big data and increase cooperation to create new innovations (Haryanti, 2019). At present, the company's capability is still limited because the data needed is owned by another entity. In the future, the private and public sectors can work together to create new systems that are safer and more effective. This is considered to encourage more companies to share information and allow other companies to use their data to develop better and better products.

\section{Readiness in Facing the Industrial Revolution 4.0 and Society 5.0}

The impact of the industrial revolution 4.0 and Society 5.0 created new opportunities for Indonesia. The 4.0 industrial revolution provides an opportunity for Indonesia to innovate. In 2019, Apple opened employment opportunities in Indonesia by choosing Indonesia as the first research \& development $(\mathrm{R} \& \mathrm{D})$ place in Asia. The Indonesian government is obliged to invite and encourage millennials as the dominant use of the internet to master digital technology. One of them is applied through vocational and industrial majors to spur polytechnics through competitiveness skills programs (Yunda, 2019).

Indonesia is committed to building a manufacturing industry that is globally competitive through the acceleration of industry 4.0, this is marked by the launch of Making Indonesia 4.0 as a road map and Indonesia's strategy to enter the digital era that is currently underway. Making Indonesia 4.0 can provide clear direction for future national industrial movements, including a focus on the development of five manufacturing sectors that will become a pilot (Kemenperin, 2019). The preparation of this road map has involved various stakeholders, ranging from government institutions, business actors, industry associations, technology providers, as well as research and education institutions. Through the commitment and active participation of all these parties, it is certain that the implementation of Industry 4.0 in Indonesia will be successful and on target.

In the face of the industrial revolution 4.0. and society 5.0. there are five industries which are the focus of industry 4.0 implementation in Indonesia, namely; food and 
beverages, textiles, automotive, electronics, and chemicals. These five industries are the backbone, and are expected to have a major influence in terms of competitiveness and contribution to the Indonesian economy towards the top 10 of the world economy in 2030. This will be an example for the application of industry 4.0, the creation of new jobs and new investments based technology. Furthermore, this is expected to attract foreign investment, improve the quality of human resources, the development of innovation ecosystems, incentives for technological investment, and harmonization of rules and policies.

Indonesia is committed to implementing Making Indonesia 4.0 and making it a national agenda. In this concept in the middle of the world focusing on Industry 4.0 (Use of Technology, Data and Automation), there is a touch of humanism in Society 5.0 will be the basic capital of this concept will be accepted by the people of Indonesia and even the world. The focus that came from Society 5.0 became a great opportunity for Indonesia to accelerate the transformation of its society. Indonesian Industrial World will face various challenges and opportunities in the industrial era 4.0, especially for Indonesian workers, there is job destruction. During the process towards society 5.0 industry, companies, and businesses must be good at seeing the challenges and opportunities of Industry 4.0. The main challenge facing Industry 4.0 is HR because the fourth industrial revolution has two phases namely the job disruption phase and the job creation phase (Natalia \& Ellitan, 2019).

Indonesia in the next 2 to 3 years will fix the development targets in the economic sector of products and services previously planned for further completion. The government must provide regulations in each region of SMEs to be able to produce 2-3 competitive and unique goods products to support budget needs such as the provision of free electricity, water as well as support for goods production aids which can then be sold locally or exported. Determination of prices according to raw materials from within the country without importing in order to reduce the increase in selling prices. Collaboration in each UKM is important. Meanwhile, the East Java region is quite good in developing SMEs, Bali and Yogyakarta which have the potential to bring in foreign tourists (Ellitan, 2018). According to Azhar (2018) there are at least three benefits of a digital platform in the Industrial Revolution 4.0 era that must be applied, namely: (1) Innovation: new business models cannot be separated from the ability of innovators to design strategies through digital platforms. In Indonesia, digital innovation takes place not only in the retail world, but also in education, catering, health, and even in the legal world. (2) Inclusivity: through digital platforms, all kinds of services can easily reach many people in various regions. This in turn will produce inclusiveness that benefits people who live far from metropolitan areas, so they can enjoy digital services. (3) Efficiency: with the development of digital platform innovation, there will automatically be efficiency, both in terms of manufacturing and marketing.

Furthermore, Azhar (2018) also explained that these three things certainly have some challenges including: First, the Problem of Control The digital economy that controls society certainly influences the public behavior that people used to shop at retail stores, now starting to switch to online shopping. Social and cultural aspects like this also need to get the attention of parties such as the government and the community so that not many retail stores will fall one by one. Second, the problem of inequality caused by people losing 
their jobs because of being replaced by robots or all the current work that can be done by a system is the most terrible scourge. The automation caused by the Digital Revolution 4.0 needs to be taken seriously so that people can prepare skills for the future so that unemployment in Indonesia can be suppressed. Third, the problem of competition is the problem of unfair competition that should be watched out for. If one platform is too dominating, then the user cannot make the choice of service that is most suitable for them. To face the industrial revolution 4.0, the national industrial sector needs a lot of improvement, especially in the aspect of technology, because mastery of technology is the main key to determine Indonesia's competitiveness in the era of industry 4.0.

Based on the article published on Indotelco (2018), in dealing with industry 4.0, Indonesia also needs to improve the quality of human resources. If this is not done then Indonesian industry will be increasingly left behind from other countries. If Indonesia does not increase its capability and competitiveness in priority (industrial) sectors, then Indonesia will not only be unable to achieve its aspirations, but will be crushed by other countries that are better prepared in the global and domestic markets. Technology transfer by local companies must be intensively carried out. Improving the quality of human resources is essential for achieving successful implementation of Making Indonesia 4.0. Furthermore, the government needs to develop an innovation ecosystem, develop a blueprint for national innovation centers, prepare pilot centers of innovation and optimize related regulations, including protection of intellectual property rights and fiscal incentives to accelerate cross-sector collaboration between private sector, public sertor and universities.

Furthermore, in dealing with competition in Industry 4.0, as stated by Hakala (2010), the strategic orientation of a business organization requires a combination of the company's value position in its market, its resources and behavioral patterns related to how the organization converts resources into products and services that are of value to their target market. Business organizations need a strategic orientation that is seen and considered as a configuration of multiple dimensions.

Business Organizations in Industry 4.0 and Society 5.0 require several things including: First is Market and Customer Orientation which are seen as organizational culture or activities that effectively create the behavior needed to achieve superior performance. This is the most effective organizational culture for creating behavior which is needed to provide the highest value to buyers, which in turn has an impact on superior company performance. The second is that business organizations must have a Technology orientation, which is the company's interest in the introduction and use of new technology, products or innovations. This is because customer value and the long-term success of the company are created through new innovations, solutions and technologies, products, services or production processes. The third is Entrepreneurial Orientation which is a strategic orientation that specifically describes aspects of entrepreneurial strategies within the company. The entrepreneurial tendency towards risk taking, innovation and proactiveness is central to entrepreneurial orientation. Entrepreneurial orientation is essentially an orientation towards growth and refers to the processes and practices that lead to 'new-entry', starting a new business, entering new markets or introducing new products to the market currently. 
The fourth is Learning Orientation and Organizational Learning as the development and acquisition of new knowledge that has the potential to influence behavior. Researchers mostly agree that market orientation and learning orientation are two things that are closely related. Learning orientation refers to company activities that broadly create and use knowledge to achieve competitive advantage which includes information about customer needs, competitors, market fluctuations, technology development to create innovation, and knowledge sharing between organizations. So there is overlapping of the market orientation which is also to find out the needs of customers, the movement of competitors and knowledge sharing. Strategic orientation is a valuable resource, contributing to competitive advantage and performance for business organizations (Ho, 2014). Determining the right strategic orientation will affect the competitive advantage of companies that compete in industry 4.0 (Puspita et al., 2020).

Indonesian society needs the main expertise in dealing with industry 4.0 , which is to have information, media and technology skills. In other words, the community must be technology literate (Muljani \& Ellitan, 2019), that is, people who have information, media and technology skills include media literacy, visual literacy, multicultural literacy, global awareness, and technology literacy. The community is also required to have learning and innovation skills which include creativity and curiosity, problem solving, and risk taking. Other skills that are no less important are skills in life and learning such as having a leadership spirit and being responsible, having ethical and moral values, productivity and accountability, flexibility and adaptation, social and cross-cultural, initiative and selfdirected. In Society 5.0. the community is also required to have the ability to communicate effectively such as being able to work in teams and collaborate, have personal and social responsibilities, in communication must be interactive, have a national and global orientation.

\section{CONCLUSIONS AND RECOMMENDATIONS}

The rapid development of science and technology has a big impact on human life. Many conveniences and innovations are obtained with the support of digital technology. Services are faster and more efficient and have a wider range of connections with online systems. Life is easier and cheaper, however, digitizing programs also has a negative impact. The role of humans is gradually taken over by automatic machines. However, this has negative impacts such as increasing numbers and increasing the burden of local and national problems.

To take advantage of opportunities and respond to the challenges of the industrial revolution 4.0, Indonesian people in particular are required to have data, technology and human literacy capabilities. Data literacy is needed by HR to improve skills in processing and analyzing big data for the benefit of improving public and business services. Technology literacy shows the ability to utilize digital technology to process data and information, while human literacy must be mastered because it shows the element of soft skills or the development of individual character to be able to collaborate, be adaptive and be wise in the era of "flood" of information. 
In the era towards society 5.0, Indonesia is expected to be able to catch up. This is caused by the vast area. Indonesia is demanded to be able to follow industry 4.0 workflows juxtaposed with society 5.0. The need for human resources (HR) in several business fields is still very massive if all of them are carried out by robotics. Indonesia is a developing country with a fairly dense population that is certainly able to align between the needs of industry 4.0 and society 5.0. Leadership in organizations must stay alive so that every innovative competitive strategy is able to run with the existing vision. To go to the era of society 5.0 the government is obliged to continuously control it.

\section{REFERENCES}

Indotelco (2018). Sepuluh Langkah Indonesia Menghadapi Revolusi Industri 4.0. Published 29 April 2018 at https://www.indotelko.com/kanal?c=id\&it=10-langkah-indonesiaindustri-4-0.

Kemenperin (2019). Making Indonesia 4.0 Bikin Industri Nasional Berdaya Saing Global di Era Digital. Published 4 April 2019 at https://www.kemenperin.go.id/artikel/ 19046/Making-Indonesia-4.0.

Azhar, A. (2018). Manfaat dan Tantangan Platform Digital di Era Revolusi Industry 4.0. Published 12 April 2018 at https://digitalentrepreneur.id/revolusi-industri-4-0.

Anis, B. J., Christiananta, B. \& Ellitan, L. (2018). The Effect of Entrepreneurship Orientation, Information Technology, Strategic Planning to Competitive Advantages with the Business Performance as Intervening Variable, International Journal of Advances Research, 6(1), 230-242.

Ellitan, L. (2018). Creating Sustainability of Small and Medium Enterprises in Surabaya and Surrounding Area. International Journal of Research Culture Society, 8(1), 157167.

Ellitan, L. \& Muljani, N. (2019). The Impact of Knowledge Management, Technology Readiness and External Environment on the Extent of E-Business Adoption. International Journal of Research Culture Society, 3(11), 63-69.

Hakala, H. (2010). Strategic Orientations in Management Literature: Three Approaches to Understanding the Interaction between Market, Technology, Entrepreneurial, and Learning Orientation. International Journal of Management Reviews, 13(2), 199217.

Hamdanunsera, H. (2018). Industri 4.0: Pengaruh Revolusi Industri pada Kewirausahaan Demi Kemandirian Ekonomi. Jurnal Nusamba, 3(2), 2-4.

Haryanti, R. (2019). Jepang Menjelang "5.0 Society" dan Era Menikmati Hidup. Published 25 January 2019 at https://properti.kompas.com/read/2019/01/25/213000921/jepangmenjelang-5.0-society-dan-era-menikmati-hidup.

Ho, Y. W. (2014). Multiple Strategic Orientation and Business Performance: A Comprehensive Investigation of High-tech Firms. Digital library of Adelaide University School of Business. Published October 2014 at https://digital.library.adelaide.edu.au. 
Huff, A. S., Floyd, S. W., Sherman, H. D., \& Terjesen, S. (2009). Strategic Management: Logic and Action. Illinois: John Willey and Sons, Inc.

Natalia, I. \& Ellitan, L. (2019). Srategies to Achieve Competitive Advantage in Industrial Revolution 4.0. International Journal of Research Culture Society, 3(6), 10-16.

Mayasari, D. (2019). Mengenal Society 5.0, Transformasi Kehidupan yang Dikembangkan Jepang. Published April 2019 at https://m.timesindonesia.co.id.

Muljani, N. \& Ellitan, L. (2019). Developing Competitiveness in Industrial Revolution 4.0. International Journal of Trend in Research and Development, 6(5), 1-3.

Obeidat, B. Y. (2016). The Effect of Strategic Orientation on Organizational Performance: The Mediating Role of Innovation. International Journal Communications, Network and System Sciences, 9, 478-505.

Puspita, L. E., Christiananta, B., \& Ellitan, L. (2020). The Effect of Strategic Orientation, Supply Chain Capability, Innovation Capability, on Competitive Advantage and Performance of Furniture Retails. International Journal of Scientific \& Technology Research, 9(03), 4521-4529.

Porter, M. E. (1981). The Contribution of Industrial Organization to Strategic Management. The Academy of Management Review, 6(4), 609-620.

Tjandrawinata, R. R. (2016). Industri 4.0: Revolusi Industri Abad Ini dan Pengaruhnya pada Bidang Kesehatan dan Bioteknologi. Medicinus, 29(1), 31-39.

Tutar, H., Nart, S., \& Bingol, D. (2015). The Effect of Strategic Orientation on Innovation Capabilities and Market Performance: The Case of ASEM. Procedia Social Behavioral Sciences, 207, 709-719.

Usman, S. (2019). Digitalisasi, Direktur Astra International: Seluruh Aplikasi akan Nyambung ke Depan. Published 20 September 2019 at https://www.merdeka.com/ teknologi/digitalisasi-direktur-astra-international-seluruh-aplikasi-akan-nyambungke-depan.html.

Yunda, N. R. (2019). Dampak Revolusi Industri 4.0 dan Society 5.0 Menciptakan Kesempatan Baru bagi Indonesia. Published 26 May 2019 at https://www.kompasiana. com/nadyarahma. 